\title{
Physico-Mechanical Characterizations of Sand Concrete: Prestressed Beams and Hollow Bricks
}

\author{
El Hadji Lèye Gueye ${ }^{1}$, Séni Tamba ${ }^{1}$, Karim Limam², Mamadou Lamine Lo ${ }^{1}$, Salah Kachkouch² \\ ${ }^{1}$ Laboratory for Water and Environmental Sciences and Technilogy, Polytechnic School of Thies, Thies, Senegal \\ ${ }^{2}$ Laboratory of Engineering Sciences for Environment, La Rochelle University, La Rochelle, France \\ Email: elhadjigueye2020@gmail.com
}

How to cite this paper: Gueye, E.H.L., Tamba, S., Limam, K., Lo, M.L. and Kachkouch, S. (2018) Physico-Mechanical Characterizations of Sand Concrete: Prestressed Beams and Hollow Bricks. Open Journal of Civil Engineering, 8, 256-270. https://doi.org/10.4236/ojce.2018.82020

Received: March 26, 2018

Accepted: June 26, 2018

Published: June 29, 2018

Copyright $\odot 2018$ by authors and Scientific Research Publishing Inc. This work is licensed under the Creative Commons Attribution International License (CC BY 4.0).

http://creativecommons.org/licenses/by/4.0/

\begin{abstract}
The use of the sand concrete makes it possible to carry out a concrete having physico-mechanical properties answering the structural exigences and having economic and environmental advantages compared to the classical concrete. The present study aims to connecting the parameters of a formulation based on an empirical formula of Caquot in order to optimize, on the one hand the couple compressive strength/absorption of water under various degrees of hygrometry, and on the other hand more precisely to use the concrete sand in the public works sector in the prefabrication of prestressed beams and hollow bricks. The results show the importance of the type of formulation used because it takes into account the percentages of fillers of sand which is a co-product (waste) of massive rock crushing. In addition, the use of fillerized sands, which are wastes of crushing basaltic rocks and containing a small percentage of fillers, is efficient in the manufacture of prestressed beams. As for the hollow bricks, a fillerized basalt sand, containing a high percentage of filler, as well as a sand dune, gives satisfactory results.
\end{abstract}

\section{Keywords}

Waste, Compressive Strength, Prestressed Beam, Hollow Bricks

\section{Introduction}

The environmental issues [1], socio-economic and sustainable development in the public works sector are increasingly taken into account by public authorities and industrial companies in all developed and developing countries. Concrete is today the most widely used building material in the world. Its success is due to 
its high mechanical properties, its durability, its geometric adaptability, its high fire resistance and especially its availability [2]. Moreover, the construction of buildings, bridges and road infrastructure requires significant amounts of quality materials. Indeed, the public authorities are looking for local and sustainable alternatives, in order to preserve the environmental quality of the country. Whatever the construction works, the characteristics of the used materials must meet minimum quality requirements. Furthermore, several categories of construction materials can be used in different construction sectors. However, in order to reduce construction costs, engineers are forced to take into account the transport distances and the means of exploitation.

However, at present, more criticisms are being made about the concrete material because of the environmental impacts generated by the production of cement, its main constituent. It should be known that, globally, 5\% of total $\mathrm{CO}_{2}$ emissions are from cement industries, which also consume $2 \%$ of total primary energy [3]. The cement is obtained by calcination of limestone and clay rocks at very high temperature of about $1450^{\circ} \mathrm{C}$. This process requires high energy consumption (coal, natural gas, fuel oil, etc.) and generates very significant $\mathrm{CO}_{2}$ emissions. In addition, the $\mathrm{CO}_{2}$ emitted by the means of transport and the production of electricity necessary for the operation of the cement plants is very important. According to a study published in June 2009 by [4], the average global amount of $\mathrm{CO}_{2}$ emitted per ton of clinker produced was $866 \mathrm{~kg} \mathrm{CO}_{2} / \mathrm{t}$ in 2006.

Country like Senegal must invest in a research and development program on sand concrete for the following reasons: development of its local resources; cost reduction of constructions in the public works sector; scarcity of aggregates; abundance of raw materials (sands and filler sands) found in almost inexhaustible quantity (Senegal is covered with more than $70 \%$ of sand on the one hand and secondly, the filler sands are co-produced by crushing massive rocks available in quarries. Indeed, the research and experiments carried out by the partners of the "SABLOCRETE" National Development Research Project [5] have shown that the technique of sand concrete pavements brings advantages in terms of the economy, the preservation of natural resources and the environment, in areas rich in sand. Then, several research studies synthesized in [6] [7] [8] [9] and [10] have shown that the mechanical performance of lightweight aggregate concrete could be sufficient for use as structural concrete. In this work we are interested in the exploitation of local materials in construction instead of using materials that require a very expensive supply, and as Senegal is very rich in sand dune we thought to exploit the sand for the manufacture of sand concrete [6] [11] [12]. Therefore, sand concretes have the same cement content as traditional concretes $\left(250\right.$ to $\left.400 \mathrm{~kg} / \mathrm{m}^{3}\right)$; the compactness is reached by a complementary addition of fines, generally limestone. Sometimes, certain uses of concrete require characteristics poorly assured by traditional concrete and sand concrete can better satisfy, among these features we quote: Handiness, cohesion and absence of segregation, small particle size and small dimension grains, surface appearance and the 
most interesting, its non-cracking character [4], which encourages us to use it as a repair material. The other interest for this material is the possibility of employing industrial fillers to increase its compactness. To have a multi-purpose construction material, denser with a very fine porosity, more impermeable and therefore more durable; silica smoke was introduced into the sand concrete formulation to see its effect on the concrete.

This article consists of a continuation of many studies already carried out on sand concretes in order to optimize the compression resistance/water absorption at different degrees of hygrometry. This experimental work deals both with the study of the physical and mechanical properties of sand concretes as a function of the water content, the addition of adjuvant and the percentage of fillers. It should also be applied on a large scale in order to confirm the possibility of the use of this concrete in the prefabrication of prestressed beams and hollow bricks.

In this study, the physical properties as well as their particle-size parameters of beach sand, sand dune and basalt $0 / 3$ are presented through a characterization process. Then, different formulations of concrete using these local materials, with or without adjuvants, are detailed in Section 3. Indeed, the specimens of concretes corresponding to real prestressed beams and real hollow bricks have been tested in laboratory to determine their mechanical performance.

\section{Characterizations of the Studied Materials}

In order to explain or illustrate the mechanical results that interest us in the context of this study, it is essential to characterize the basic constituents of sand concretes. These are mainly natural sand, beach or dune, basalt fillerized sands, Portland Cement CEM I 42.5, Pozzolith 390 HE adjuvant, water.

Density and water absorption of sands are measured according to articles 8 and 9 of standard NF EN 1097-6. The results obtained are shown in Table 1. We also determined other physical parameters including ES at sight, ES at the piston and SS in the laboratory.

\subsection{The Physical Properties of the Used Materials}

Table 1 shows that the physical characteristics (intrinsic) of the used materials can vary according to the types of rocks, their alteration or their degree of fracturing.

Table 1. Physical properties of the used materials.

\begin{tabular}{ccccccc}
\hline Building material & $\begin{array}{c}\text { Real density } \\
\left(\mathrm{g} / \mathrm{cm}^{3}\right)\end{array}$ & $\begin{array}{c}\text { Apparent density } \\
\left(\mathrm{g} / \mathrm{cm}^{3}\right)\end{array}$ & Abs (\%) & $\begin{array}{c}\text { ES at sight } \\
(\%)\end{array}$ & $\begin{array}{c}\text { ES in the } \\
\text { piston (\%) }\end{array}$ & SS \\
\hline Sand of dune & 2.65 & 1.51 & 0.98 & 81 & 74 & 4390 \\
Basalt $0 / 3$ & 2.99 & 1.50 & 1.96 & - & - & 1611 \\
Beach sand & 2.57 & 1.46 & - & 96.5 & 82 & - \\
Cement & 3.10 & 1.15 & - & - & - & 3000
\end{tabular}

Abs: Absorptivity ES at sight $=$ Equivalent of Sand at sight ES at piston $=$ Equivalent of sand in the piston SS: Specific Surface. 
The densities of the various sands, found in this study are close to that of silico-calcareous granulate because they are not only of the order of $2.65 \mathrm{~g} / \mathrm{cm}^{3}$ but also the apparent densities found are around 2 (two) times lower than the actual densities. The absorptivity rates and specific surface areas are high, which justifies the importance of the amount of mixing water compared to conventional concretes. The specific surface of the cement found is correct. Indeed, it must be between 2700 and $5500 \mathrm{~cm}^{2} / \mathrm{g}$ except for natural fast cements (CPN) which are very fine (up to $7500 \mathrm{~cm}^{2} / \mathrm{g}$ ). According to the values recommended for sand equivalent by Dreux, the used sands of red dunes are "clean sands", with a low percentage of fine clay, which is ideal for high quality concretes.

Concretes with sand dune require much more water than those with beach sand because dune sand is less clean. Indeed, the ES values are lower. In addition, their specific surface area is such that the fillers can screen between the grains of sand, gravels and the binder, thus leading to poor adhesion between the mortar and grains.

The beach sands used in the study, are also based on ES values classified as "very clean sand". However, the almost total absence of clayey fines may lead to a lack of concrete plasticity that will have to be compensated by an increase in water dosage.

Still in the physical characterization of the materials used, the results of particle analyses are synthesized in the following paragraph.

\subsection{Particle-Size Parameters}

Table 2 presents particle size parameters which were determined from an analysis which makes it possible to determine the respective size and weight percentages of the different families of grains constituting the specimen. It applies to all aggregates with a nominal dimension of less than or equal to $90 \mathrm{~mm}$, excluding fillers.

The natural sands (beach or dune) and the fillerized $0 / 3$ basalt sand containing a small percentage of fillers used have a uniform particle size. Indeed, the coefficients $\mathrm{Cu}$ vary between 1.88 and 2.82 that is to say less than 3 (three). On the other hand, with the fillerized sand having a high percentage of fillers and the $0 / 3$ basalt used with the dune sands in the study have a spread particle size. Indeed, the values of $\mathrm{Cu}$ vary between 8.5 and 18 that is to say greater than 3 .

This table also shows that the fillerized basalt sands have a continuous granulometry $(\mathrm{Cu}>2)$. The basalt $0 / 3$ used with dune sands and those containing a high percentage of fillers have a continuous granularity greater than 2 and in addition are very well graded $(\mathrm{Cu} \geq 4$ and $1<\mathrm{Cc}<3)$. The $0 / 3$ basalt containing a small percentage of fillers has a narrow particle size according to the BNQ $(\mathrm{Bu}-$ reau of Quebec Standards) because $2<\mathrm{Cu}<5$. From the same table, we notice that natural sands are thinner than crushed sands because their Mf are lower. The finesse module of dune sand is lower than that of beach sand, so dune sand is richer in fine elements. A large amount of fines could cause problems in 
Table 2. Particle size parameters.

\begin{tabular}{cccccc}
\hline Parameters particle-size & \% fillers $(<80 \mu \mathrm{m})$ & $\mathrm{Cu}$ & $\mathrm{Cc}$ & So & $\mathrm{Mf}$ \\
\hline $\begin{array}{c}\text { Sand of dune } \\
\text { Beach sand }\end{array}$ & 1.5 & 1.95 & 1.23 & 1.23 & 1.36 \\
$\begin{array}{c}\text { Basalt 0/3 used with the sand of } \\
\text { dune }\end{array}$ & 0 & 1.88 & 1.37 & 1.15 & 1.48 \\
$\begin{array}{c}\text { Basalt 0/3 with a high \% of } \\
\text { fillers }\end{array}$ & 4.25 & 8.5 & 1.05 & 2.19 & 2.83 \\
$\begin{array}{c}\text { Basalte 0/3 with a low \% de } \\
\text { fillers }\end{array}$ & 9.35 & 18 & 2.34 & 2.32 & 2.71 \\
\hline
\end{tabular}

concrete because they have a strong need for water that leads to their swelling and an important stiffening of concretes.

After characterizing the local materials, we proceeded to the formulation of the concrete and the manufacture of the samples in order to test them in the laboratory to evaluate their mechanical performances through subsidence measurements. For this, several configurations of formulation are studied by integrating or not adjuvants.

\section{Studied Sand Concrete Formulation}

Concerning concrete, the major step must be in the formulation of the product before the evaluation of the mechanical properties in the laboratory. This paragraph will detail this crucial step.

\subsection{Sand Concrete Manufacturing}

The formulation is based on an empirical formula of Caquot [13] and will be done without adjuvant, then with Pozzolith $390 \mathrm{HE}$ in order to work under favorable conditions.

The purpose of this physico-mechanical characterization of sand formulated concrete is to see if it is really possible to create an alternative using the sand fillerized of basalt (waste) in the production of prestressed beams which are used to make a floor containing, hollow bricks and a slab of compression. $0 \mathrm{~cm}$ on the fresh concrete slump conditions of prefabrication and a resistance of 300 bars in 2 days on cubic samples in stops $10 \mathrm{~cm}$ after curing.

This procedure makes it possible to determine certain physical properties whose results are indicated in Tables 3-6 Physical properties of sand concretes made with beach sand.

For concrete made with beach sand, the results are reported in Table 3 and Table 4.

Table 3 and Table 4 show on the side of fresh concrete following the formulation using the beach sand, the results are satisfactory and conclusive. Indeed, $\mathrm{E}=(1201-160 \mathrm{l})$ and $\mathrm{E}=(118 \mathrm{l}+2 \mathrm{l}$ adjuvant $)$ until $\mathrm{E}=(168 \mathrm{l}+2 \mathrm{l}$ adjuvant $)$ we have subsidence $0 \mathrm{~cm}$. 
Table 3. Case 1, Dosages of constituents of non-adjuvanted sand concrete.

\begin{tabular}{|c|c|c|c|c|c|c|c|c|c|}
\hline Elements & \multicolumn{9}{|c|}{ Dry weight $\mathrm{kg} / \mathrm{m}^{3}$ of sand concrete } \\
\hline Beach sand & & & & & 570 & & & & \\
\hline Basaltfillerized Sand & & & & & 973.41 & & & & \\
\hline Cement & & & & & 400 & & & & \\
\hline Water & 120 & 130 & 140 & 150 & 160 & 170 & 180 & 190 & 200 \\
\hline Subsidence $(\mathrm{cm})$ & 0 & 0 & 0 & 0 & 0 & 1 & 2 & 2.4 & 2.5 \\
\hline Density of hardened concrete & 2250 & 2200 & 2500 & 2500 & 2450 & 2400 & 2400 & 2400 & 2350 \\
\hline
\end{tabular}

Table 4. Case 2, Dosages of constituents of the adjuvanted sand concrete.

\begin{tabular}{|c|c|c|c|c|c|c|c|c|c|}
\hline Elements & \multicolumn{9}{|c|}{ Dry weight $\mathrm{kg} / \mathrm{m}^{3}$ of sand concrete } \\
\hline Beach sand & \multicolumn{9}{|c|}{570} \\
\hline Basaltfillerized sand & \multicolumn{9}{|c|}{973.41} \\
\hline Cement & \multicolumn{9}{|c|}{400} \\
\hline Pozzolith 390 HE (litres) & \multicolumn{9}{|c|}{2} \\
\hline Water & 118 & 128 & 138 & 148 & 158 & 168 & 178 & 188 & 198 \\
\hline Subsidences $(\mathrm{cm})$ & 0 & 0 & 0 & 0 & 0 & 0 & 0,7 & 1.1 & 1.2 \\
\hline $\begin{array}{l}\text { Density of hardened concrete } \\
\qquad\left(\mathrm{kg} / \mathrm{m}^{3}\right)\end{array}$ & 2300 & 2300 & 2400 & 2450 & 2450 & 2400 & 2400 & 2350 & 2400 \\
\hline
\end{tabular}

Table 5. Case 3, dosages constituent of non-adjuvanted sand concrete.

\begin{tabular}{ccccccc}
\hline Elements & \multicolumn{5}{c}{ Dry weight $\mathrm{kg} / \mathrm{m}^{3}$ of sand concrete } \\
\hline Sand of dune & \multicolumn{7}{c}{510} \\
Basaltfillerized sand & \multicolumn{7}{c}{1045} \\
Cement & 130 & 140 & 150 & 160 & 170 & 180 \\
Water & 0 & 0 & 0 & 0 & 0 & 0,6 \\
Subsidences $(\mathrm{cm})$ & 2300 & 2300 & 2350 & 2400 & 2400 & 2350 \\
\hline Density of hardened concrete $\left(\mathrm{kg} / \mathrm{m}^{3}\right)$ & & & & & \\
\end{tabular}

Table 6. Case 2, Dosages of constituents of the adjuvanted sand concrete.

\begin{tabular}{|c|c|c|c|c|c|c|}
\hline Elements & \multicolumn{6}{|c|}{ Dry weight $\mathrm{kg} / \mathrm{m}^{3}$ of sand concrete } \\
\hline Sand of dune & \multicolumn{6}{|c|}{510} \\
\hline Basaltfillerized sand & \multicolumn{6}{|c|}{1045} \\
\hline Cement & \multicolumn{6}{|c|}{400} \\
\hline Adjuvant (L) & \multicolumn{6}{|c|}{2} \\
\hline Water (L) & 128 & 138 & 148 & 158 & 168 & 178 \\
\hline Subsidences $(\mathrm{cm})$ & 0 & 0 & 0 & 0 & 0 & 0,3 \\
\hline Density of hardened concrete $\left(\mathrm{kg} / \mathrm{m}^{3}\right)$ & 2300 & 2450 & 2400 & 2425 & 2500 & 2400 \\
\hline
\end{tabular}




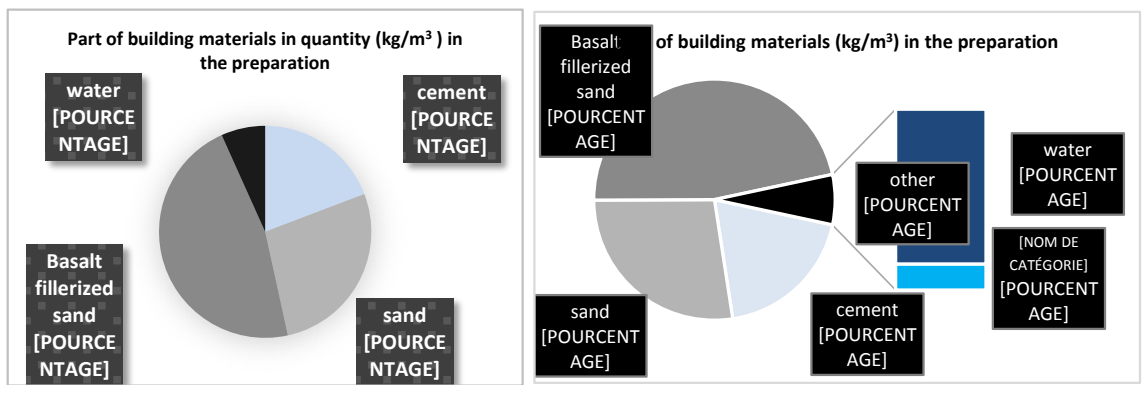

Figure 1. Sand concrete preparation respectively without and with adjuvant.

\subsection{Physical properties of Sand Concretes Made with Dune Sand}

For concrete made with dune sands, the results are shown in Table 5 and Table 6.

Table 5 and Table 6 show on the side of fresh concrete following the formulation using the beach sand, the results are satisfactory and conclusive. Indeed, $\mathrm{E}=1301-170 \mathrm{l}$ and $\mathrm{E}=(128 \mathrm{l}+2 \mathrm{l}$ adjuvant $)$ until $\mathrm{E}=(168 \mathrm{l}+2 \mathrm{l}$ adjuvant $)$ we have subsidence $0 \mathrm{~cm}$.

Table 3 and Table 6 show that the densities of sand concretes, made to produce prestressed beams and hollow bricks, vary between 2150 and $2500 \mathrm{~kg} / \mathrm{m}^{3}$ while the variation of conventional concrete is between 2500 and $2600 \mathrm{~kg} / \mathrm{m}^{3}$. Moreover, the mechanical strength is also a function of the density. Indeed, if it is higher, it can generate greater characteristic resistances. As a result, conventional concrete is less lightweight but more resistant than sand concrete.

The evolution of subsidence according to the $\mathrm{E} / \mathrm{C}$ ratio is well illustrated in the four cases below corresponding to Figure 2.

Figure 2 shows the evolution of Cases 1 to 4 subsidence as a function of the E/C ratio following the exploitation of the results in Table 3 and Table 6. The results of the formulations in the production of the prestressed beams and hollow bricks, show subsidence variations in the cone of Abrams between 0 and 3 $\mathrm{cm}$ depending on the amount of mixing water, which corresponds to that fresh concrete of firm to very firm consistency. Figure 2 also shows that the subsidence increases when the amount of water increases.

In cases 1 and 2, reflecting the use of beach sands, the $\mathrm{E} / \mathrm{C}$ ratios that vary between 0.295 and 0.42 correspond to a fresh concrete subsidence of 0 . On the other hand, beyond 0.42 the subsidence is no longer zero. This is not required in the prefabrication of prestressed beams.

In cases 3 and 4, reflecting the use of dune sands, the $\mathrm{E} / \mathrm{C}$ ratios that vary between 0.32 and 0.425 correspond to a fresh concrete subsidence of 0 . On the other hand, beyond 0.425 the subsidence is no longer zero. This is not required in the prefabrication of prestressed beams.

The results of this study allowed us to identify the mechanical characteristics of each material without or with adjuvants. Indeed, these characteristics are used to make real specimens of concrete elements namely; prestressed beams and 


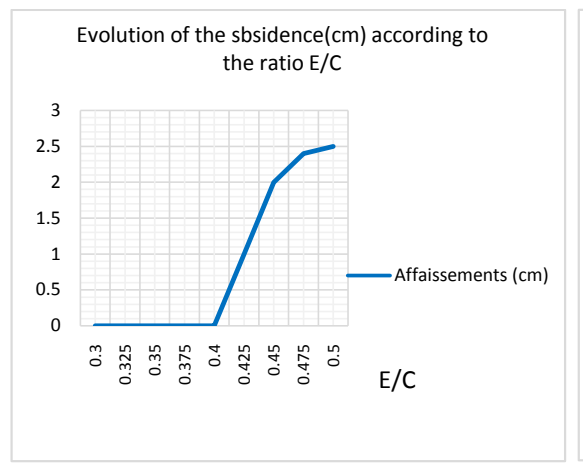

Case 1. no-adjuvant

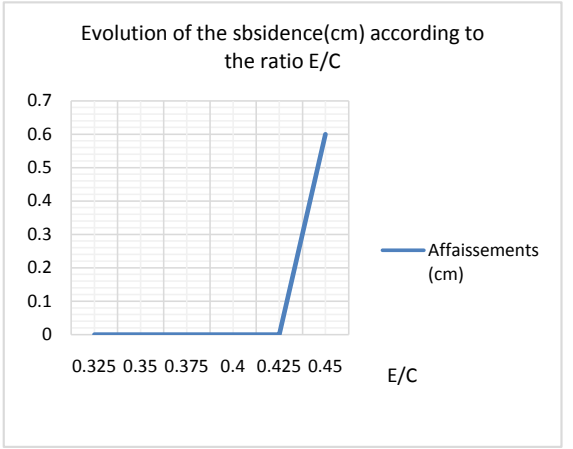

Case 3. no-adjuvant

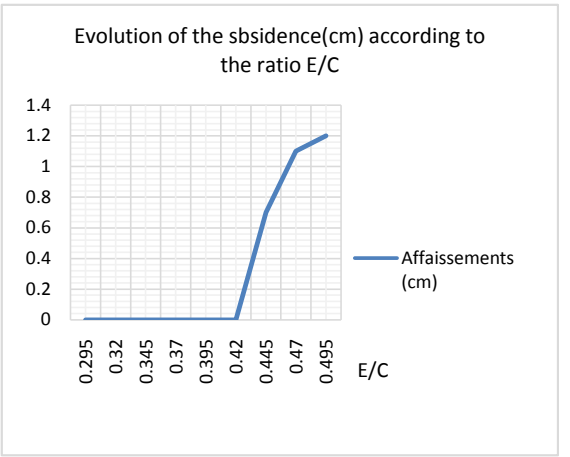

Case 2. with-adjuvant

Evolution of the sbsidence $(\mathrm{cm})$ according to the ratio $\mathrm{E} / \mathrm{C}$

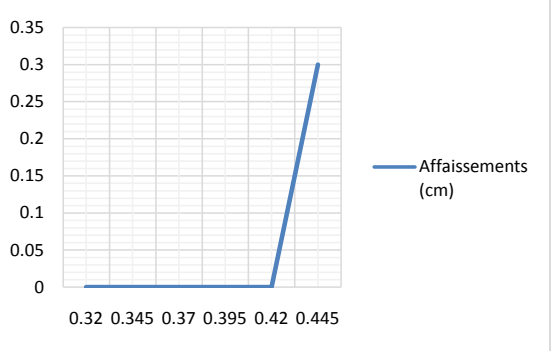

Case 4. with-adjuvant

Figure 2. Evolutions of subsidence, cases 1-4.

hollow bricks. The results of the experimental study on the mechanical behavior of these specimens are presented in the following section.

\section{Mechanical Tests: Prestressed Beams and Hollow Bricks}

Still in the production of prestressed beams, in terms of requirements i.e. $0 \mathrm{~cm}$ in subsidence at the fresh concrete, it's also has a pressure of 300 bars strength after 2 days of curing that is requested. Because of this, we performed mechanical tests on standardized specimens to evaluate the capacity of a sand concrete formulated as previously described, to support a stress level without damage. The tests are conclusive, applications for the manufacture of prefabricated building elements have been create (Figure 3) [14]. It is a question of:

- Beams of $12 \mathrm{~cm}$ high and containing 3 strands called 312 type beams in good conditions of prefabricated elements at the factory. Their performance requires respect in their manufacturing, some fundamental phases until the completion of the finished products.

- Hollow bricks or hollow blocks with dimension of $12 \mathrm{~cm} \times 20 \mathrm{~cm} \times 50 \mathrm{~cm}$ and weighing $13,250 \mathrm{~kg}$, high weight compared to that manufactured at the factory $(11.5 \mathrm{~kg})$ because the basalt is denser than limestone. In this case the use of fillerized limestone sand would have given better results. This intermediate element is supported on the beams without intervention of external device.

The following paragraph shows the experimental approach that has made it 


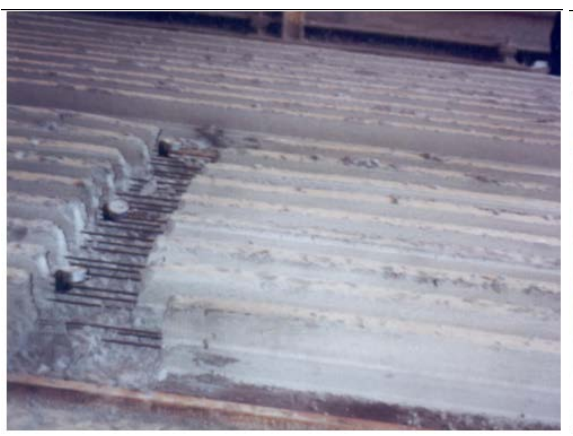

(a)

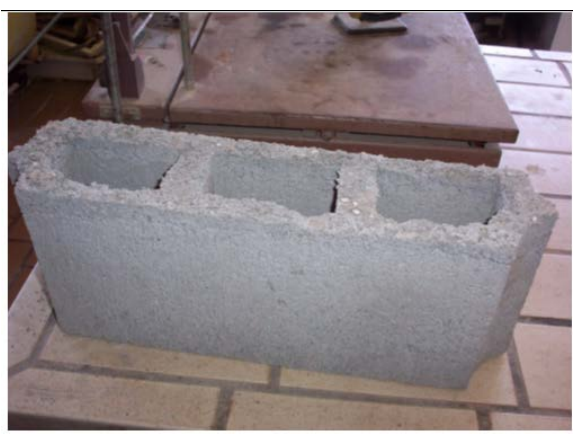

(b)

Figure 3. Prefabricated building elements. (a) Prestressed Beam create with the sand concrete; (b) Hollow bricks of concrete sand.

possible to ensure a good match with the construction requirements of building elements.

\subsection{Experimental Approach}

The composition of a concrete depends on the desired qualities [15]. If the essential quality sought is the compressive strength, a solid mixture with a minimum of vacuum, that is to say a high compactness and a small amount of mixing water, must be sought. Once the test pieces were prepared according to the formulation defined above, we subjected the test pieces to the test bench. The measurement of the mechanical compressive strengths of the studied sand concretes was carried out on cubic specimens of $10 \mathrm{~cm}$ ridge. They are vibrated at most for one minute on a vibrating table and exposed to the air. Then, after 2, 7 and 28 days the test pieces are crushed using a press (see Figure 4).

The results of the crushing tests are shown in Figures 6-9. Throughout the study at the level of the results and analyzes in the next section, the fcj (compressive strength) are expressed in bars.

\subsection{Results and Statistical Analyzes}

The results of mechanical compressive strengths are shown in Figures 5-8 which show the evolution of sand concrete with or without adjuvant according to the ratio E/C. This is to check the performance using different natural sand. In fact, the nature of the fillerized sands and the adjuvant (Pozzolith $390 \mathrm{HE}$ ) does not change.

For concrete with natural beach sand, the results are shown in Figure 5 and Figure 6.

For concrete with natural dune sand the results are shown in Figure 8 and Figure 9.

On the profiles of evolution of the resistance according to the ratio E/C presented in figures above, we note that they have the same tendencies of evolution; one realizes that the resistance decreases with the increase of the ratio $\mathrm{E} / \mathrm{C}$ as it is 


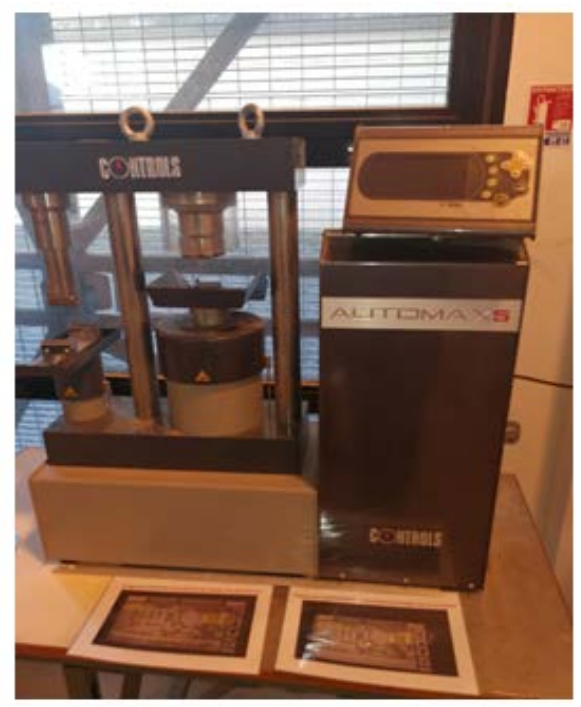

Figure 4. Press used for simple compression tests.

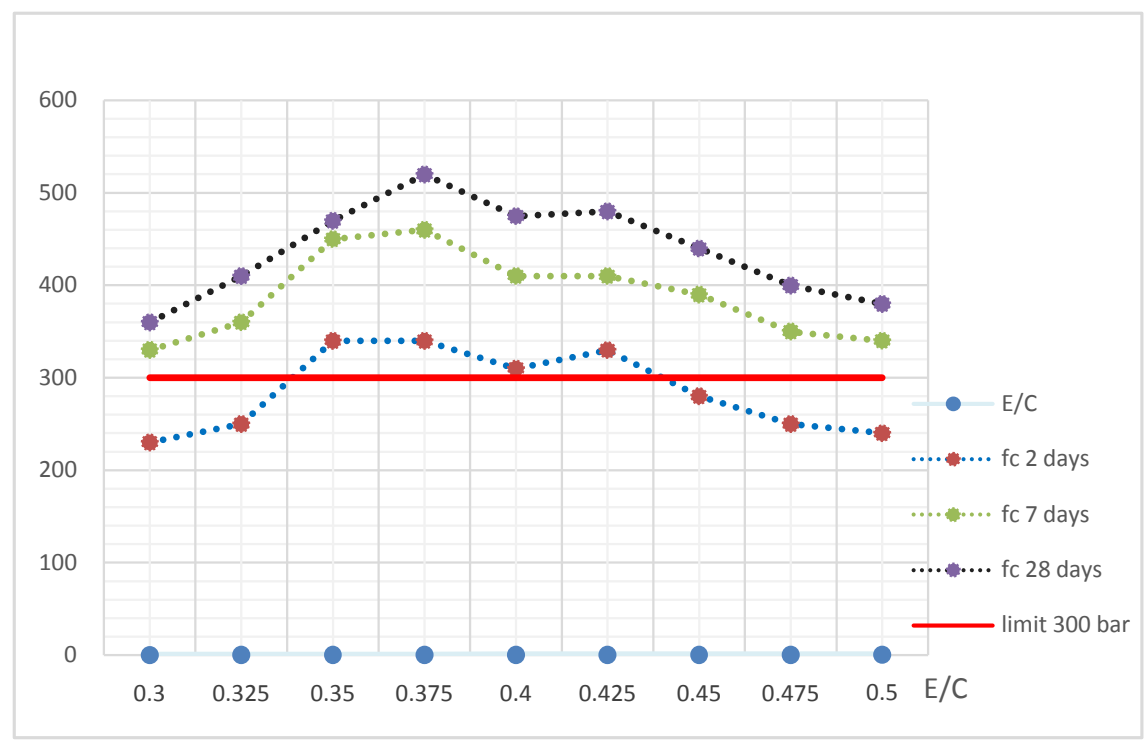

Figure 5. Evolution of adjuvanted concrete.

the case for conventional concretes. But for very low values or too high value of the ratio $\mathrm{E} / \mathrm{C}, \mathrm{C}$, we observe very weak resistances, consequence of the partial hydration of the cement.

Compared to prefabrication of prestressed beams, sand concrete could be used. Indeed, the production requires concrete compressive strength equal to 300 bars at two days and subsidence of 0 (zero).

From the results of the formulations and mechanical tests our sand concrete compositions have the desired qualities. But the use of $0 / 3$ basalt containing a high percentage of fillers according to the factory production ratio gave unsatisfactory results on fc2 (Figure 9) because often less than 300 bars. This situation cannot be explained by insufficient mixing water as it increases with fillers. In 


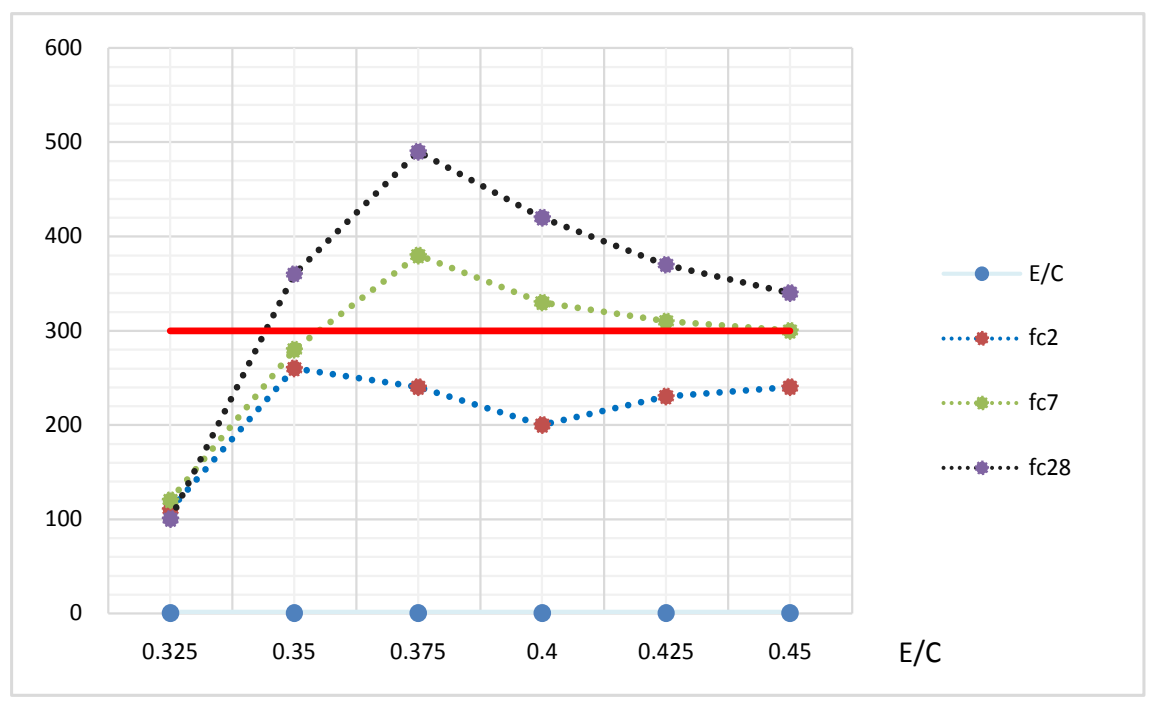

Figure 6. Evolution of no adjuvanted concrete.

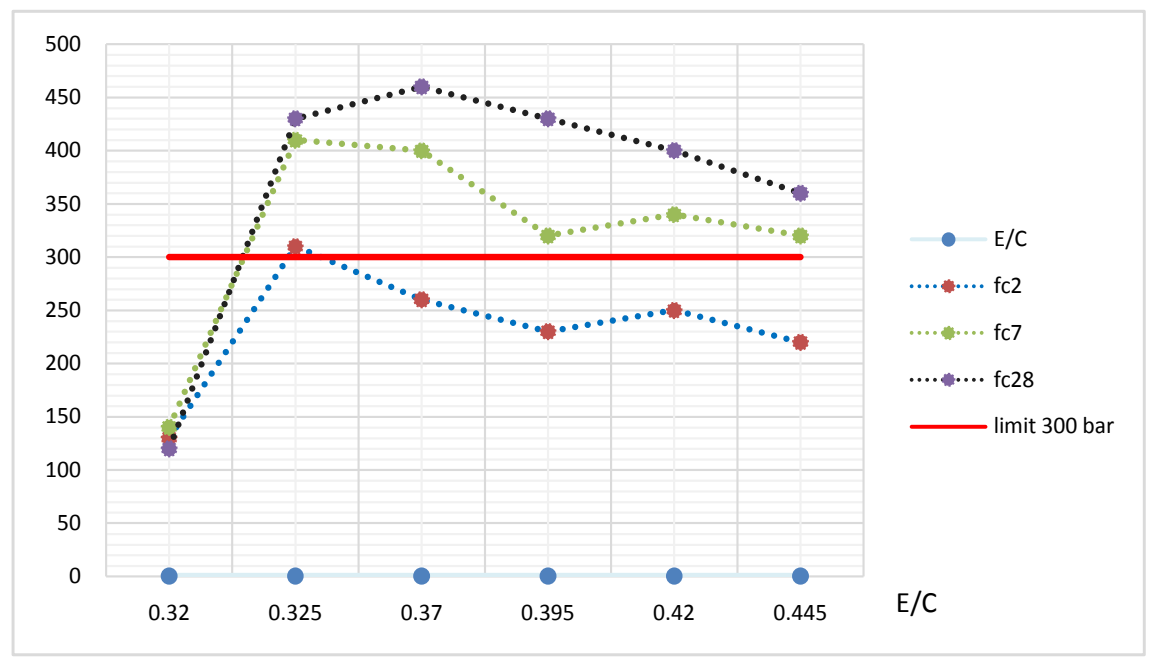

Figure 7. Evolution of no adjuvanted concrete according to the report E/C.

fact, if the fines correspond to alteration residues, it is obvious in this case that although they play a role of filling which can improve the compactness, the fact remains that they will be able to reduce the resistance.

In order to enlarge the results obtained from a statistical point of view, we have associated statistical elements (standard deviation, mean, maximum and minimum) with the sand concrete mechanical resistances which are summarized in Tables 7-10.

For concrete with beach sand the results of the calculations are shown in Table 7 and Table 8.

For concrete with dune sand the results of the calculations are shown in Table 9 and Table 10.

In fact, Tables 7-10 show the possibilities of confirming the results of the study of the production of prestressed beams and hollow bricks from the point 


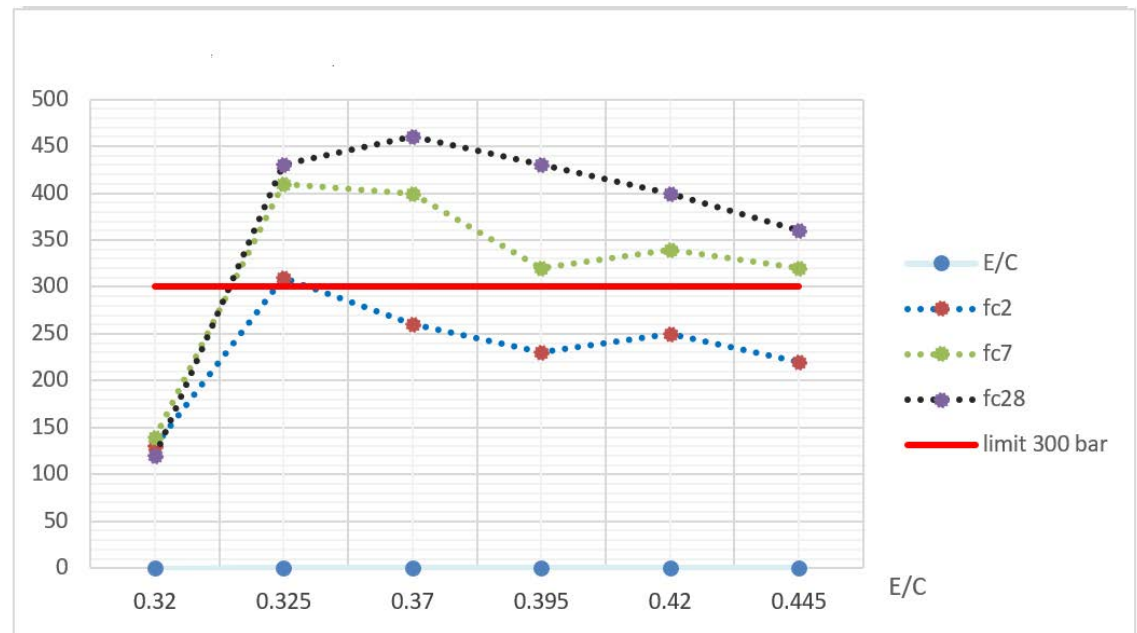

Figure 8. Evolution of adjuvanted concrete according to the report E/C.

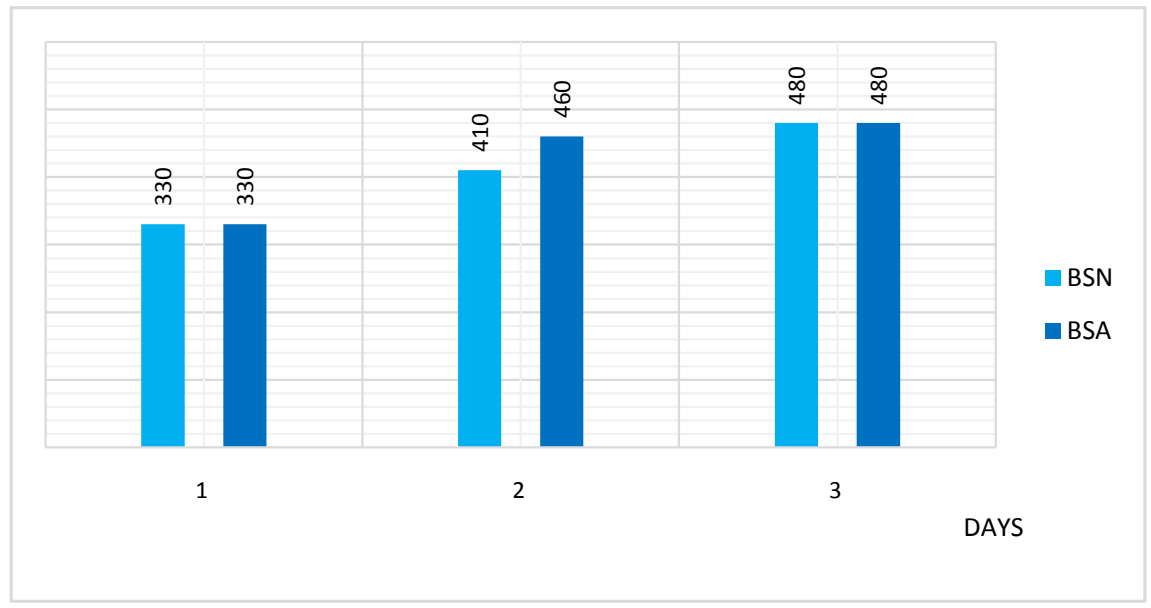

Figure 9. Average evolution of BSN with low percentage of fillers at $\mathrm{E} / \mathrm{C}=0.425$.

Table 7. Statistics elements of not adjuvanted concrete evolution.

\begin{tabular}{ccccc}
\hline Element & Standard deviation & Mean & Maximum & Minimum \\
\hline E/C & 0.068 & 0.400 & 0.5 & 0.3 \\
fc2 & 45.031 & 285.556 & 340 & 230 \\
fc7 & 47.288 & 388.889 & 460 & 330 \\
fc28 & 53.098 & 437.222 & 520 & 360 \\
\hline
\end{tabular}

Table 8. Statistics elements of evolution adjuvanted concrete.

\begin{tabular}{ccccc}
\hline Element & Standard deviation & Mean & Maximum & Minimum \\
\hline E/C & 0.068 & 0.400 & 0.5 & 0.3 \\
fc2 & 45.031 & 285.556 & 340 & 230 \\
fc7 & 47.288 & 388.889 & 460 & 330 \\
fc28 & 53.098 & 437.222 & 520 & 360 \\
\hline
\end{tabular}


Table 9. Statistics elements of not adjuvanted concrete evolution.

\begin{tabular}{ccccc}
\hline Element & Standard deviation & Mean & Maximum & Minimum \\
\hline E/C & 0.047 & 0.388 & 0.45 & 0.325 \\
fc2 & 54.283 & 213.333 & 260 & 110 \\
fc7 & 88.468 & 286.667 & 380 & 120 \\
fc28 & 132.313 & 346.667 & 490 & 100 \\
\hline
\end{tabular}

Table 10. Statistics elements of adjuvanted concrete evolution.

\begin{tabular}{ccccc}
\hline Element & Standard deviation & Mean & Maximum & Minimum \\
\hline E/C & 0.051 & 0.379 & 0.445 & 0.32 \\
fc2 & 59.554 & 233.333 & 310 & 130 \\
fc7 & 97.245 & 321.667 & 410 & 140 \\
fc28 & 125.485723 & 366.66 & 460 & 120 \\
\hline
\end{tabular}

of view of statistics. Indeed, the use of these statistical data will make it possible to verify in a wider sense the feasibility of other applications.

Furthermore, it is noted that the use of the adjuvant (Pozzolith $390 \mathrm{HE}$ ) is important because it reduces subsidence and increases the compressive strength and the density. Thus, the amount of mixing water used is equal to the previously determined volume of water decreased by the volume of the adjuvant.

But, with the Pozzolith 390 HE, the increase of the resistance is not systematic on all the results of the mechanical tests for example:

Figure 9 shows that according to the formulation method with the beach sands at $\mathrm{E} / \mathrm{C}=0.425$ the resistances are the same at 2 and 28 days for the two concretes of adjuvanted sand or not (BSA or BSN). But the resistance increases in 7 days. An average evolution of the resistance is highlighted.

Figure 10 shows that the increase in the resistance of the sand concrete at $\mathrm{E} / \mathrm{C}=$ 0.44 is greater after the ratio of the prefabrication plant. A good evolution is noted when the concrete is adjuvanted. Indeed, it increases of about 200 bars in 2 days, 180 bars in 7 days and 190 bars in 28 days.

Figure 11 shows a bad evolution of the BSN at $\mathrm{E} / \mathrm{C}=0.38$ because with adjuvant there is a decrease of the resistance at 2 days ( 40 bars), at 7 days ( 35 bars) and at 28 days ( 20 bars) according to the ratio of the prefabrication plant in November 2003 with a high percentage of fines.

Therefore, Figures 9-11 show that Pozzolith 390 HE is not a very suitable adjuvant to increasing compressive strength in the case of sand concretes because it does not improve its mechanical performance definitively and permanently [16].

However, concrete with the use of fillerized basalt sands containing a low percentage of fillers sand concretes have subsidence about 0 . On the other hand, with $0 / 3$ basalt containing a high percentage of fillers, it is difficult to have a non-adjuvant sand concrete of zero subsidence because the fillers cause a rapid 


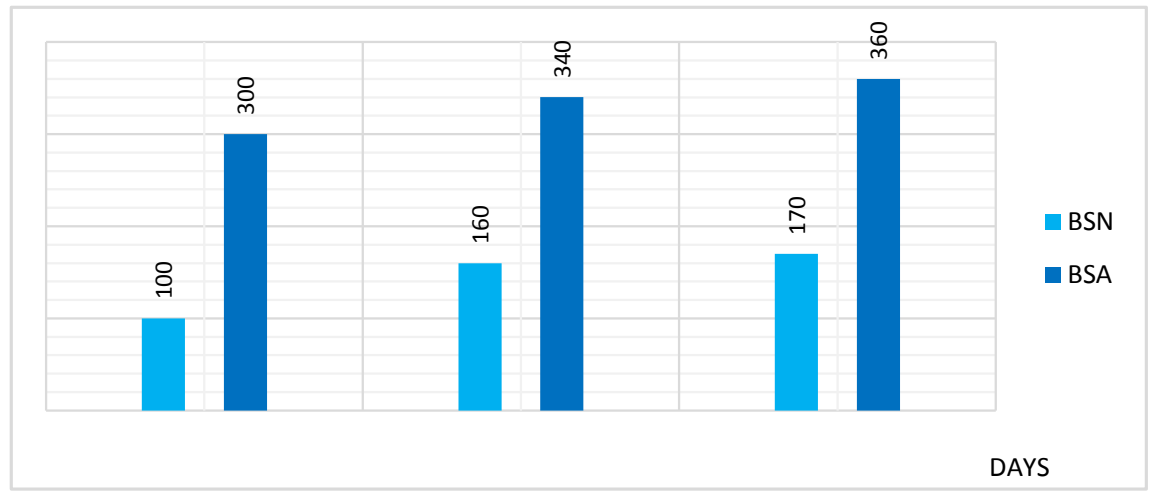

Figure 10. Good evolution of BSA after correction at $\mathrm{E} / \mathrm{C}=0.44$.

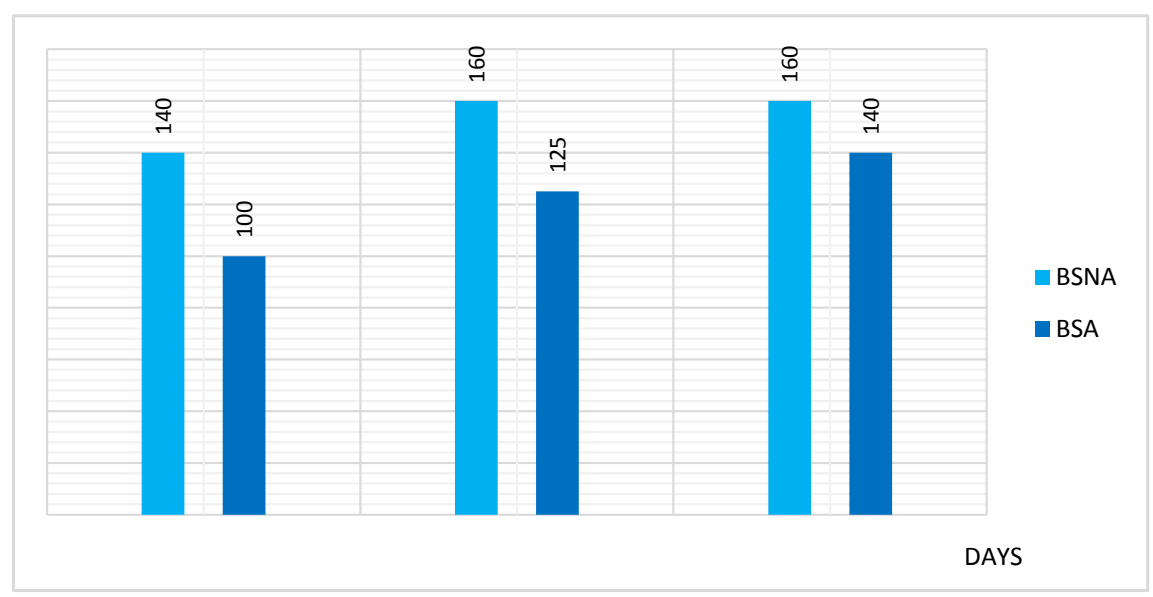

Figure 11. Bad evolution of BSA with high percentage of fillers at $\mathrm{E} / \mathrm{C}=0.38$.

subsidence. And the higher their content, the greater the amount of mixing water is important.

\section{Conclusions}

The study of sand concrete that we conducted has shown that prestressed beams of sand concrete can replace those of conventional concrete; also we noted that the hollow bricks can also be made with sand concrete; on the other hand dune sands can replace beach sands in this production of prefabricated elements because they have comparable characteristics and are less expensive and are of ecological interest.

The use of sand concrete makes it possible to solve several problems and offer several advantages among which, we can quote, the diversification in the choice of materials which makes it possible to reduce the overexploitation of massive rock quarries; the valorization of a waste in substitution of the aggregates of big caliber in the public works sector; finally the reduction of the cost of the prestressed beams which will allow a better popularization of the product in Senegal.

In perspective, we will guide the research towards social housing and road paving interlocking seen the gains that will obviously be recorded in order to 
significantly reduce the costs of collective housing and improve the living environment populations especially in flood urban areas.

\section{References}

[1] Damtoft, J.S., Lukasik, J., Herfort, D., Sorrentino, D. and Gartner, E.M. (2008) Sustainable Development and Climate Change Initiatives. Cement and Concrete Research, 38, 115-127. https://doi.org/10.1016/j.cemconres.2007.09.008

[2] Meyer, C. (2009) The Greening of the Concrete Industry. Cement and Concrete Composites, 31, 601-605.

[3] Hendriks, C.A., Worrell, E., de Jager, D., Blok, K. and Riemer, P. (2004) Emission Reduction of Greenhouse Gases from the Cement Industry. Greenhouse Gases Control Technologies Conference, Août 2004.

[4] Cement Industry Energy and $\mathrm{CO}_{2}$ Performance (2009) Getting the Numbers Right. Publication of World Business Council for Sustainable Development (WBCSD), 30 Juin 2009.

[5] Presse de l'Ecole Nationale des Ponts et Chaussées (1994) Béton de sable, Caractéristiques et pratique d'utilisation. (Projet SABLOCRETE), édition. Association Amicale des Ingénieurs Anciens Elèves de L'Ecole Nationale des Ponts et Chaussées, 15-71.

[6] Cisse, I.K. (1996) Contribution à la valorisation des matériaux locaux au Sénégal: Application aux bétons de sable. $323 \mathrm{p}$.

[7] DIEDHIOU.M. (2001) Conception de support de lignes électriques en béton de sable précontraint. Mémoire de fin d'études d'ingénieur, 68 p.

[8] Rahmathulla Noufal, E. and Manju, U. (2016) I-Sand: An Environment Friendly Alternative to River Sand in Reinforced Cement Concrete Constructions. Construction and Building Materials, 125, 1152-1157

[9] Hasdemir, S., Tugrul, A. and Yilmaz, M. (2016) The Effect of Natural Sand Composition on Concrete Strength. Construction and Building Materials, 112, 940-948.

[10] Laid Bedadi et Mohamed Tahar Bentebba (2011) Etude expérimentale d'un béton de sable de dune pour la préfabrication des dalles et prédalles armées et faiblement armées.

[11] Diop, S., Samb, M., Diome, F. and Fall, M. (2015) Etude de caractérisation des matériaux de la carrière de Sindia (Sénégal occidental) pour une utilisation en géotechnique routière. Revue CAMES Science appliquée de P ingénieur, 1, 79-85.

[12] Cisse, K. and Lauuerbe, M. (1999) Caractérisation des bétons de sable routiers compacté : application au cas du Sénégal. Matériaux et Constructions, 32, 151-157.

[13] Caquot, A. (1937) Le rôle des matériaux inertes dans le béton. Mémoire de la société desingénieurs civils de France, 562-582.

[14] PREBAT (2004) Production Report of march 2004, Dakar-SENEGAL.

[15] Min, K.-H. (2018) Punching and Local Damages of Fiber and FRP Reinforced Concrete under Low-Velocity Impact Load. Open Journal of Civil Engineering, 8, 64-81. https://doi.org/10.4236/ojce.2018.81006

[16] Xiong, H.B. and Calvo, M.A.H. (2015) High-Rise Residential Reinforced Concrete Building Optimisation. Open Journal of Civil Engineering, 5, 437-450. https://doi.org/10.4236/ojce.2015.54044 